\title{
Effects of some endocrine disruptors on the secretory and proliferative activity of the regenerating rat adrenal cortex
}

\author{
LUDWIK K. MALENDOWICZ ${ }^{1}$, MARCIN TREJTER ${ }^{1}$, PIERA REBUFFAT ${ }^{2}$, \\ AGNIESKA ZIOLKOWSKA ${ }^{1}$, GASTONE G. NUSSDORFER ${ }^{2}$ and MARIOLA MAJCHRZAK ${ }^{1}$ \\ ${ }^{1}$ Department of Histology and Embryology, School of Medicine, PL-60781 Poznan, Poland; \\ ${ }^{2}$ Department of Human Anatomy and Physiology (Section of Anatomy), University of Padua, I-35121 Padua, Italy
}

Received February 6, 2006; Accepted March 23, 2006

\begin{abstract}
The effects of some endocrine disruptors that possess estrogen-like activity on the secretion and growth of regenerating rat adrenal cortex have been investigated in ovariectomized (OVX) and sham-OVX rats. As reference groups, dexamethasone (Dx)-administered sham-OVX and 17ß-estradiol-administered OVX animals were used. Dx, estradiol and endocrine disruptors were subcutaneously injected daily at a dose of 3 nmoles/100 g for 10 consecutive days after surgery, and adrenal enucleation was performed on day 5 of the experiment. Dx and genistein significantly decreased corticosterone plasma concentration (as measured by RIA) in sham-OVX rats with regenerating adrenals, while other disruptors (eusolex, procymidone, linurone, resveratrol, bisphenol-A and and silymarin) were ineffective. Mitotic index (as assayed by the stachmokinetic method with vincristine) was not changed by either Dx or disruptors. Estradiol significantly increased and genistein significantly lowered corticosterone blood level in OVX rats; similar effects were induced in the mitotic index of regenerating adrenals, but the changes were not significant. Eusolex increased the mitotic index, without altering the level of circulating corticosterone. Collectively, our findings allow us to conclude that, of the endocrine disruptors tested, only genistein is able to suppress the secretory activity of regenerating adrenal cortex, this Dx-like effect being apparently unrelated to its estrogen-like activity, and only eusolex enhances the proliferation rate of regenerating adrenal, the effect being conceivably connected with its estrogen-like activity.
\end{abstract}

\section{Introduction}

The best recognized endocrine disrupting properties of

Correspondence to: Professor G.G. Nussdorfer, Department of Human Anatomy and Physiology, Section of Anatomy, Via Gabelli 65, I-35121 Padova, Italy

E-mail: gastone.nusdorfer@unipd.it

Key words: genistein, eusolex, regenerating rat adrenal cortex, steroid secretion, cell proliferation chemicals are those connected with their estrogenic activity. Unexpectedly, the current testing strategies to assess the effects of the endocrine disruptors have omitted adrenal glands, as far as either steroidogenesis or growth are concerned (1).

One of the classic in vivo models to study adrenocortical cell proliferation and secretory function is enucleation-induced regeneration (for review, see refs. 2-6), which not only primarily depends on pituitary ACTH release (7-11), but is also influenced by several neural and endocrine signals (12-17). Hence, we investigated the effects of several endocrine disruptors on glucocorticoid (corticosterone) secretion and the proliferative activity of the regenerating rat adrenal cortex.

\section{Materials and methods}

Animals and reagents. Adult female Wistar rats (100-120 g body weight), bred in our laboratory facilities, were kept under a $14 / 10$-h light/dark cycle at $23^{\circ} \mathrm{C}$, and maintained on a standard diet and tap water ad libitum. The study protocol was approved by the local ethics committee for animal studies. Dexamethasone (Dx), 17ß-estradiol, diphenylolpropane (bisphenol-A; BSP) and benzophenone-3 (eusolex-4360) were purchased from Merck \& Co. (Whitehouse Station, NJ). Resveratrol was obtained from Nabio Biotech. Co. (Shanghai, China), and vincristine was from Gedeon-Richter (Budapest, Hungary). Genistein, procymidone, linurone, silymarin and all other reagents were provided by Sigma-Aldrich Corp. (St. Louis, MO).

Surgical procedures. Bilateral ovariectomy (OVX), and left adrenal enucleation and contralateral gland removal (adrenal cortex regeneration) were carried out via dorsal approach and under ether anesthesia, as previously described (14). Operated animals were given $0.9 \% \mathrm{NaCl}$ to drink, and were sacrificed 5 days after adrenal enucleation.

Experimental protocol. Groups of sham-OVX rats $(\mathrm{n}=8)$ were given daily subcutaneous (sc) injections of 3 nmoles/100 $\mathrm{g}$ of Dx, genistein, eusolex, procymidon, linuron, resveratrol, BSP or silymarin dissolved in $0.2 \mathrm{ml} 0.9 \% \mathrm{NaCl}$ for 10 consecutive days. Groups of OVX rats $(n=8)$ were treated with estradiol, genistein or eusolex, as detailed above. Control rats received sc injections of vehicle. The treatment started immediately after surgery and, on day 5 of the experiment, all rats underwent 

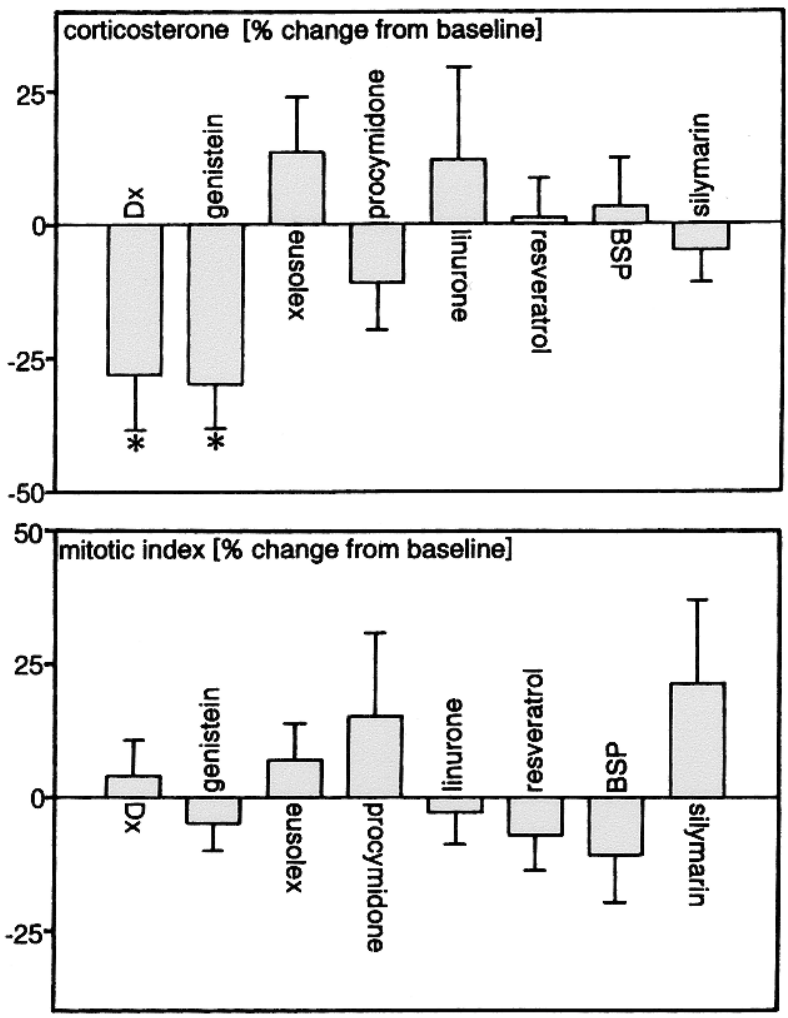

Figure 1. Effects of Dx and endocrine disruptors on the plasma corticosterone concentration (upper panel) and mitotic index of regenerating adrenal (lower panel) of sham-OVX rats. Results, expressed as percent change from controls are the mean \pm SEM of 8 separate experiments. ${ }^{*} \mathrm{p}<0.05$ from the respective control value.

adrenal enucleation. All animals were given an intraperitoneal injection of $0.1 \mathrm{mg} / 100 \mathrm{~g}$ of vincristine $3 \mathrm{~h}$ before being sacrificed. Rats were decapitated at 11:00 am; their trunk blood was collected in the presence of EDTA $(1 \mathrm{mg} / \mathrm{ml})$, and plasma was separated and stored at $-36^{\circ} \mathrm{C}$. Regenerating adrenals were promply removed.

Corticosterone assay. Corticosterone was extracted from plasma and its concentration measured by RIA, as previously detailed (18). RIA sensitivity was $50 \mathrm{pg} / \mathrm{ml}$. Intra- and interassay CVs were $7 \%$ and $9 \%$, respectively.

Cell proliferation. Regenerating adrenals were fixed in Bouin's solution for $24 \mathrm{~h}$, embedded in paraffin and sectioned at 5$6 \mu \mathrm{m}$. Sections were stained with hematoxylin and eosin. The mitotic index (\%o of metaphase-arrested cells) was calculated at $400 \mathrm{x}$, by counting 5,000 cells in the regenerating adrenal parenchyma (14).

Statistics. Data, expressed as percent change from control value, were the mean \pm SEM of 8 separate experiments. Statistical comparison was performed by ANOVA followed by Student's t-test.

\section{Results}

Dx and genistein significantly decreased corticosterone plasma concentration in sham-OVX rats with regenerating adrenals,

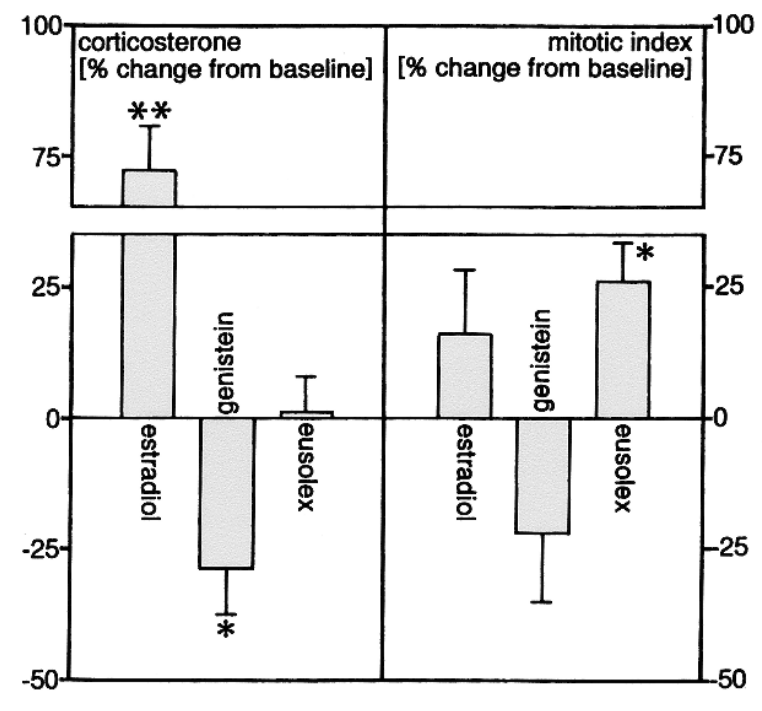

Figure 2. Effects of estradiol, genistein and eusolex on the plasma corticosterone concentration (left panel) and mitotic index of regenerating adrenal (right panel) of OVX rats. Results, expressed as percent change from controls, are the mean \pm SEM of 8 separate experiments. ${ }^{*} \mathrm{p}<0.05$ and ${ }^{* *} \mathrm{p}<0.01$ from the respective control value.

while other chemicals were ineffective (Fig. 1, upper panel). In these animals, mitotic index was not significantly changed by any disruptor (Fig. 2, lower panel).

Estradiol markedly increased and genistein lowered corticosterone plasma concentration in OVX rats with regenerating adrenals. Similar effects were induced in the mitotic index, but the changes were not significant. Conversely, eusolex did not change corticosterone blood level, but evoked a significant rise in the mitotic index (Fig. 2).

\section{Discussion}

The effects of various endocrine disruptors on the glucocorticoid secretion and growth of regenerating adrenal cortex were investigated. As reference groups, DX-administered sham-OVX and estradiol-administered OVX animals were used. As expected, Dx lowered corticosterone secretion but did not affect proliferative activity. This last finding is at variance with those reported previously $(2,4,7,8)$ but is in keeping with the earlier observation of the lack of effect of both hydrocortisone and Dx on the growth of regenerating rat adrenal cortex (19). In the other reference group, estradiol was found to enhance corticosterone secretion without affecting the regenerating-adrenal growth rate. This finding is in partial disagreement with the reported stimulating affect of estradiol on both secretion and growth of rat adrenals (reviewed in ref. 20). However, it must be emphasized that the effects of estradiol on the adrenal cortex are known to depend on either the experimental model used (e.g. intact versus gonadectomized animal) or the dose (physiological versus supraphysiological doses) and the chemical nature (natural versus synthetic estradiol) (referenced in ref. 20).

Our present findings show that, of the endocrine disruptors tested, only genistein and, to a less extent, eusolex affect the function of regenerating rat adrenals, despite the fact that all these chemicals are reported to exert sex hormone-like effects. 
The chemical and functional characterics of genistein and eusolex will be briefly discussed in relation to their adrenocortical effects.

The isoflavone, genistein, possesses structural characteristics similar to that of 173 -estradiol, which enables it to exert estrogenic and antiestrogenic effects $(21,23)$. Genistein was found to affect cell proliferation and differentiation, apoptosis, angiogenesis, and cell adhesion and migration. Evidence has been provided that isoflavones can also exert biological effects independent of their estrogenic properties (24), which seems to be the case for its action on the regenerating rat adrenal cortex. In fact, in contrast with estradiol, genistein was found to lower corticosterone secretion from regenerating adrenals. This effect resembles that of Dx, thereby suggesting that genistein exerts a glucocorticoid-like action. Genistein is known to be a potent inhibitor of tyrosine kinase (TK) $(25,26)$, an enzyme that seems to play a role in steroid synthesis (27-29). However, TK also activates MAPK, whose involvement in the stimulation of adrenocortical growth is well documented (30-34). Genistein was not found to affect the growth of regenerating adrenals; therefore, it is unlikely that the inhibitory action of this isoflavone is connected with its anti-TK activity.

The benzophenone, eusolex, is a UV absorber that displays a certain structural relationship with steroid hormones (35). It was shown to exert variable estrogen-like uterotrophic effects (36) and to enhance the proliferative activity of the MCF-7 breast cancer cell line (37). The presently observed stimulation of the regenerating adrenal growth in OVX rats may be related to the estradiol-like action of eusolex. However, this contention does not agree with the lack of effect of this benzophenone on corticosterone secretion.

For the reader's convenience, we wish to spend few words on the other endocrine disruptors studied. Procymidone and linurone are commonly used pesticides that are reported to interact with steroid-hormone receptors to variously affect sex-hormone synthesis and to exert different effects on sex hormone-target organs and tissues (38-43). BSP and some alkylphenols (p-nonylphenol and p-tert-octylphenol) have been found to possess estrogenic activity, as they display uterotrophic effects, disrupt the estrus cycle in rodents (44) and cause testis atrophy in rats (45). The phytoalexin, resveratrol, structurally resembles $17 ß$-estradiol, and possesses estrogenreceptor modulating activity, thereby affecting numerous biological functions $(22,45)$. Finally, silymarin, a plant flavonoid, has been shown to have preventive effects against carcinogenesis and cell damage in various animal models, as well as anti-oxidant, anti-inflammatory and immunomodulatory activity (47). None of these chemicals was found to affect the secretion and growth of regenerating rat adrenals. However, this does not rule out the possibility that, due to their estrogenlike properties, these chemicals may affect the function of normal adrenocortical cells, as preliminary in vitro results seem to suggest.

To conclude, our study shows that, among the various endocrine disruptors tested, only genistein exerts inhibitory effects on glucocorticoid secretion from regenerating rat adrenals in vivo. This observation stresses that great caution must be used in interpreting the results of experiments on adrenal cortex where genistein is used as a TK inhibitor.

\section{Acknowledgements}

This study was supported by European Community grant EURISKED (EVK1-CT 2002-00128). We wish to thank Miss A. Coi for her secretarial support and invaluable help in the provision of bibliographic items.

\section{References}

1. Harvey PW and Everett DJ: The adrenal cortex and steroidogenesis as cellular and molecular targets for toxicity: critical omissions from regulatory endocrine disrupter screening strategies for human health? J Appl Toxicol 23: 81-87, 2003.

2. Dallman MF: Control of adrenocortical growth in vivo. Endocr Res 10: 213-242, 1985.

3. Taki TM and Nickerson PA: Differentiation and proliferation of adrenocortical cells during the early stages of regeneration. Lab Invest 53: 91-100, 1985.

4. Nussdorfer GG: Cytophysiology of the adrenal cortex. Int Rev Cytol 98: 1-405, 1986.

5. Mitani F, Suzuki H, Hata JI, Ogishima T, Shimada H and Ishimura Y: A novel cell layer without corticosteroid-synthesizing enzymes in rat adrenal cortex: histochemical detection and possible physiological role. Endocrinology 135: 431-438, 1994.

6. Sarria L, Losada J and Bueno-Lopez JL: Immunohistochemical analysis of adrenal proliferation and corticosterone expression in experimental adrenal regeneration. Histol Histopathol 10: 603-609, 1995.

7. Stachowiak A, Nussdorfer GG and Malendowicz LK: Proliferation and distribution of adrenocortical cells in the gland of ACTH- or dexamethasone-treated rats. Histol Histopathol 5: 25-29, 1990.

8. Lesniewska B, Nowak KW and Malendowicz LK: Dexamethasone-induced adrenal cortex atrophy and recovery of the gland from partial, steroid-induced atrophy. Exp Clin Endocrinol 100: 133-139, 1992 .

9. Perone MJ, Chisari AN, Gomez-Dumm CL, Spinedi E and Estivariz FE: Bilateral adrenal enucleation-induced changes in adenohypophyseal pro-opiomelanocortin (POMC)-related peptides synthesis and secretion: a comparative study with adrenalectomized rats. J Endocrinol Invest 20: 172-182, 1997.

10. Engeland WC and Levay-Young BK: Changes in the glomerulosa cell phenotype during adrenal regeneration in rats. Am J Physiol 276: R1374-R1382, 1999.

11. Miyamoto H, Mitani F, Mukai K, Suematsu M and Ishimura Y: Studies on cytogenesis in adult rat adrenal cortex: circadian and zonal variations and their modulation by adrenocorticotropic hormone. J Biochem 126: 1175-1183, 1999.

12. Ulrich-Lay YM and Engeland WC: Hyperinnervation during adrenal regeneration influences the rate of functional recovery. Neuroendocrinology 71: 107-123, 2000.

13. Ulrich-Lay YM, Fraticelli AI and Engeland WC: Capsaicinsensitive nerve fibers: a potential extra-ACTH mechanism participating in adrenal regeneration in rats. Microsc Res Tech 61: 252-258, 2003.

14. Markowska A, Neri G, Hochol A, Nowak M, Nussdorfer GG and Malendowicz LK: Effects of leptin and leptin fragments on steroid secretion and proliferative activity of regenerating rat adrenal cortex. Int J Mol Med 13: 139-141, 2004.

15. Albertin G, Rucinski M, Carraro G, Forneris M, Andreis PG, Malendowicz LK and Nussdorfer GG: Adrenomedullin and vascular endothelium growth factor genes are overexpressed in the regenerating rat adrenal cortex, and AM and VEGF reciprocally enhance their mRNA expression in cultured rat adrenocortical cells. Int J Mol Med 16: 431-435, 2005.

16. Malendowicz LK, Rebuffat P, Tortorella C, Nussdorfer GG, Ziolkowska A and Hochol A: Effects of met-enkephalin on cell proliferation in different models of adrenocortical-cell growth. Int J Mol Med 15: 841-845, 2005.

17. Trejter M, Carraro G, Rucinski M, Hochol A, Rebuffat P, Nussdorfer GG and Malendowicz LK: Arginin-vasopressin regulates proliferative activity of the regenerating rat adrenal cortex. Int J Mol Med 15: 993-997, 2005.

18. Hochol A, Albertin G, Nussdorfer GG, Spinazzi R, Ziolkowska A, Rucinski M and Malendowicz LK: Effects of neuropeptides B and $\mathrm{W}$ on the secretion and growth of rat adrenocortical cells. Int J Mol Med 14: 843-847, 2004. 
19. Zieleniewski J and Nowakowska-Jankiewicz B: The effect of hydrocortisone and dexamethasone on the mitotic activity of regenerating adrenal cortex. Acta Med Pol 27: 97-99, 1986.

20. Malendowicz LK: Cytophysiology of the Mammalian Adrenal Cortex as Related to Sex, Gonadectomy and Gonadal Hormones. PTPN Press, Poznan, pp1-233, 1994.

21. Yang J, Nakagawa H, Tsuta K and Tsubura A: Influence of perinatal genistein exposure on the development of MNU-induced mammary carcinoma in female Sprague-Dawley rats. Cancer Lett 149: 171-179, 2000.

22. Cos P, De Bruyne T, Apers S, Van den Berghe D, Pieters L and Vlietinck AJ: Phytoestrogens: recent developments. Planta Med 69: 589-599, 2003.

23. Lephart ED, Setchell KD, Handa RJ and Lund TD: Behavioral effects of endocrine-disrupting substances: phytoestrogens. ILAR J 45: 443-454, 2004.

24. Valachovicova T, Slivova V and Sliva D: Cellular and physiological effects of soy flavonoids. Mini Rev Med Chem 4: 881-887, 2004.

25. Akiyama T, Ishida J, Nakagawa S, Ogawara H, Watanabe $S$, Itoh N, Shibuya M and Fukami Y: Genistein a specific inhibitor of tyrosine-specific protein kinases. J Biol Chem 262: 5592-5595, 1987.

26. Dhar A, Paul AK and Shukla SD: Platelet-activating factor stimulation of tyrosine kinase and its relationship to phospholipase $\mathrm{C}$ in rabbit platelets: studies with genistein and monoclonal antibody to phosphotyrosine. Mol Pharmacol 37: 519-525, 1990.

27. Aptel HB, Burnay MM, Rossier MF and Capponi AM: The role of tyrosine kinases in capacitative calcium influx-mediated aldosterone production in bovine adrenal zona glomerulosa cells. J Endocrinol 163: 131-138, 1999.

28. Kigoshi T, Imaizumi N, Yoshida J, Nakagawa A, Nakano S, Nishio $\mathrm{M}$ and Uchida $\mathrm{K}$ : Involvement of tyrosine kinase in citrate-stimulated aldosterone production in bovine glomerulosa cells. Am J Physiol 279: E140-E145, 2000.

29. Sirianni R, Carr BR, Andò S and Rainey WE: Inhibition of Src tyrosine kinase stimulates adrenal androgen production. J Mol Endocrinol 30: 287-299, 2003.

30. Andreis PG, Markowska A, Champion HC, Mazzocchi G, Malendowicz LK and Nussdorfer GG: Adrenomedullin enhances cell proliferation and deoxyribonucleic acid synthesis in rat adrenal zona glomerulosa: receptor subtype involved and signaling mechanism. Endocrinology 141: 2098-2104, 2000.

31. Mazzocchi G, Rossi GP, Malendowicz LK, Champion HC and Nussdorfer GG: Endothelin-1[1-31], acting as an ETA-receptor selective agonist stimulates proliferation of cultured rat zona glomerulosa cells. FEBS Lett 487: 194-198, 2000.

32. Andreis PG, Malendowicz LK, Trejter M, Neri G, Spinazzi R, Rossi GP and Nussdorfer GG: Ghrelin and growth hormone secretagogue receptor are expressed in the rat adrenal cortex: evidence that ghrelin stimulates the growth, but not the secretory activity of adrenal cells. FEBS Lett 536: 173-179, 2003.

33. Mazzocchi G, Neri G, Rucinski M, Rebuffat P, Spinazzi R, Malendowicz LK and Nussdorfer GG: Ghrelin enhances the growth of cultured human adrenal zona glomerulosa cells by exerting MAPK-mediated proliferogenic and antiapoptotic effects. Peptides 25: 1269-1277, 2004.
34. Spinazzi R, Ziolkowska A, Neri G, Nowak M, Rebuffat P, Nussdorfer GG, Andreis PG and Malendowicz LK: Orexins modulate the growth of cultured rat adrenocortical cell, acting through type 1 and type 2 receptors coupled to the MAPK p42/ p44 and p38-dependent cascades. Int J Mol Med 15: 847-852, 2005.

35. Gustavsson-Gonzales H, Farbrot A and Larko O: Percutaneous absorption of benzophenone-3, a common component of topical sunscreens. Clin Exp Dermatol 27: 691-694, 2002.

36. Schlecht C, Klammer H, Jarry H and Wuttke W: Effects of estradiol, benzophenone-2 and benzophenone-3 on the expression pattern of the estrogen receptors (ER) alpha and beta, the estrogen receptor-related receptor 1 (ERR1) and the aryl hydrocarbon receptor $(\mathrm{AhR})$ in adult ovariectomized rats. Toxicology 205: 123-130, 2004.

37. Schlumpf M, Cotton B, Conscience M, Haller V, Steinmann B and Liechtensteiger $\mathrm{W}$ : In vitro and in vivo estrogenicity of $\mathrm{UV}$ screens. Environ Health Perspect 109: 239-244, 2001.

38. Vingaard AM, Hnida C, Breinholt V and Larsen JC: Screening of selected pesticides for inhibition of CYP19 aromatase activity in vitro. Toxicol In Vitro 14: 227-234, 2000.

39. Kang IH, Kim HS, Shin JH, Kim TS, Moon HJ, Kim IY, Choi KS, Kil KS, Park YI, Dong MS and Han SY: Comparison of antiandrogenic activity of flutamide, vinclozolin, procymidone, linuron and p'-DDE in rodent 10-day Hershberger assay. Toxicology 199: 145-159, 2004.

40. Kennel PF, Pallen CT and Bars RG: Evaluation of the rodent Hershberger assay using three reference endocrine disrupters (androgen and antiandrogens) Reprod Toxicol 18: 63-73, 2004.

41. Radice S, Fumagalli R, Chiesara E, Ferraris M, Frigerio S and Marabini L: Estrogenic activity of procymidone in rainbow trout (Oncorhynchus mykiss) hepatocytes: a possible mechanism of action. Chem Biol Interact 147: 185-193, 2004.

42. Rosen MB, Wilson VS, Schmid JE and Gray LE: Gene expression analysis in the ventral prostate of rats exposed to vinclozolin or procymidone. Reprod Toxicol 19: 367-379, 2005.

43. Seidlova-Wuttke D, Jarry H, Christoffel J, Rimoldi G and Wuttke W: Effects of bisphenol-A (BPA), dibutylphtalate (DBP), benzophenone-2 (BP2), procymidone (Proc), and linurone (Lin) on fat tissue, a variety of hormones and metabolic parameters: a 3 months comparison with effects of estradiol (E2) in ovariectomized (ovx) rats. Toxicology 213: 13-24, 2005.

44. Ashby J: Increasing the sensitivity of the rodent uterotrophic assay to estrogens, with particular reference to bisphenol A. Environ Health Perspect 109: 1091-1094, 2001.

45. Hirose A, Koizumi M and Hasegawa R: Bisphenol and alkylphenols. Nippon Rinsho 58: 2428-2433, 2000.

46. Granados-Soto V: Pleiotropic effects of resveratrol. Drug News Perspect 16: 299-307, 2003.

47. Katiyar SK: Silymarin and skin cancer prevention: antiinflammatory, antioxidant and immunomodulatory effects. Int J Oncol 26: 169-176, 2005. 